\title{
Idaho Chemical Processing Plant Low-Activity Waste Grout Stabilization Development Program FY-97 Status Report
}

Engineering Laboratory

Idaho National 


\title{
Idaho Chemical Processing Plant Low-Activity Waste Grout Stabilization Development Program FY-97 Status Report
}

\author{
A. K. Herbst \\ D. W. Marshall \\ J. A. McCray
}

Published February 1998

DISTRIBUTION OF THIS DOCUMENT IS UNLMMTED
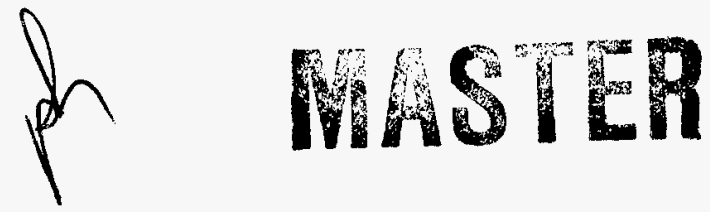

Idaho National Engineering and Environmental Laboratory

Department

Lockheed Martin Idaho Technologies Company Idaho Falls, Idaho 83415 


\section{DISCLAIMER}

This report was prepared as an account of work sponsored by an agency of the United States Government. Neither the United States Government nor any agency thereof, nor any of their employees, makes any warranty, express or implied, or assumes any legal liability or responsibility for the accuracy, completeness, or usefulpess of any information, apparatus, product, or process disclosed, or represents that its use would not infringe privately owned rights. Reference herein to any specific commercial product, process, or service by trade name, trademark, manufacturer, or otherwise does not necessarily constitute or imply its endorsement, recommendation, or favoring by the United States Government or any agency thereof. The views and opinions of authors expressed herein do not necessarily state or reflect those of the United States Government or.any agency thereof. 


\section{SUMMARY}

The general purpose of the Grout Development Program is to solidify and stabilize the liquid low-activity wastes (LAW) generated at the Idaho Chemical Processing Plant (ICPP). It is anticipated that LAW will be produced from the following: 1) chemical separation of the tank farm high-activity sodium-bearing waste, 2) retrieval, dissolution, and chemical separation of the aluminum, zirconium, and sodium calcines, 3) facility decontamination processes, and 4) process equipment waste. Grout formulation studies for sodium-bearing LAW, including decontamination and process equipment waste, continued this fiscal year. A second task was to develop a grout formulation to solidify potential process residual heels in the tank farm vessels when the vessels are closed.

For sodium-bearing LAW, the grouting of denitrated solids continues to be a viable process to achieve maximum volume reduction. A grout made with 35 $\mathrm{wt} \%$ denitrated solids meets minimum strengths and leach resistance while reducing volume to $1 / 5$ the original volume. If volume continues to be a driving requirement, this process is the most effective.

Two methods of grouting the liquid sodium-bearing LAW were found this year. The waste can be grouted if the $\mathrm{pH}$ is between 1 and 3 or if the $\mathrm{pH}$ is greater than 11. Both processes produce acceptable strength and leach resistance while increasing the volume by $11 / 2$ times. The short-term tests look promising, but long-term tests (thermal cycling and immersion) need to be completed. If volume ceases to be a driver, these processes could become cost-effective.

It was determined that the tank farm vessel process residual heels can be grouted if the heels are diluted. The heel could be diluted by repeatedly adding an equal volume of aluminum nitrate solution or water to the heel and jetting off as much solution as possible. It is recommended that premixed grout be used to displace heel so that it could be further jetted or pumped out of the tank. This method would remove as much heel as possible from the tank and leave a solid grout for tank closure.

For FY-98, continued wasteform qualification is planned in the areas of compressive strength following sample immersion and thermal cycle testing. The grout formulations for both LAW and tank heels will be refined and characterized for mixture tolerances, order of addition, fluid flow, set time, cure rate, and heat of hydration. A grout pilot plant is planned for 2004 to test the equipment needed to concentrate, denitrate, and mix the grout and waste. Wasteform qualification testing is needed on full-scale disposal drums produced in the pilot plant to qualify the grout process and the grouted waste. 


\section{ACKNOWLEDGMENTS}

The authors express their gratitude to the following persons for their assistance in this program:

Dr. Barry Sheetz, Materials Research Laboratory, Pennsylvania State University

Eric Olson, S. M. Stoller Corp., Boulder, Colorado

Toshinori Shigemitsu, Nuclear Fuel Industries, Ltd, Osaka, Japan

Darrell Dietz, Ash Grove Cement Company, Inkom, Idaho

Jerry Rose, Blue Circle Cement, Inc., Sparrows Point, Maryland

Cary Sargent, Valley Ready Mix, Inc., Idaho Falls, Idaho

Richard Simmons, AEA Technology, Dorchester, Dorset, United Kingdom

Dr. Steve Palethorpe, AEA Technology, Seascale, Cumbria, United

Kingdom 


\section{CONTENTS}

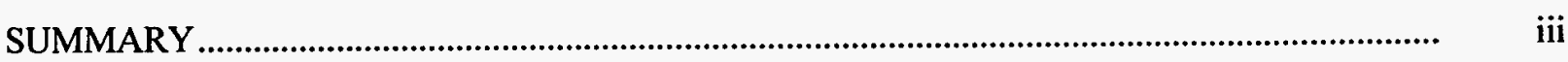

ACKNOWLEDGMENTS ..................................................................................................... v

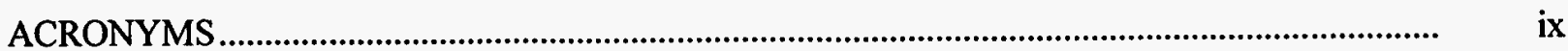

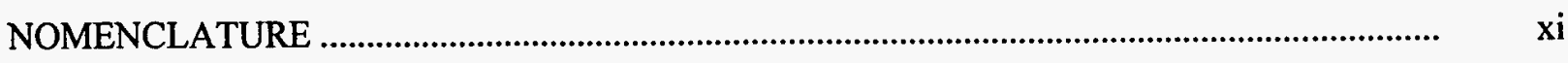

INTRODUCTION .................................................................................................................

GROUTING OF DENITRATED SOLID SODIUM-BEARING LAW ........................................... 2

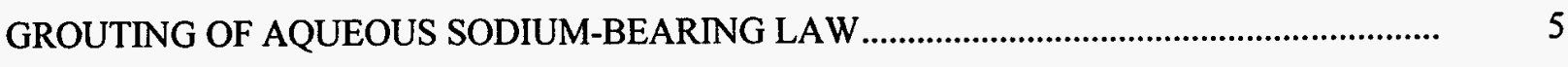

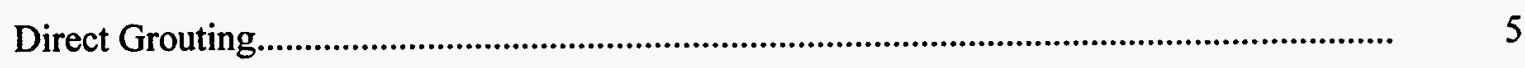

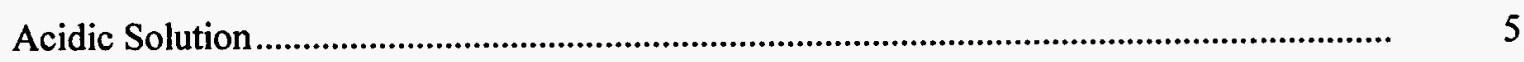

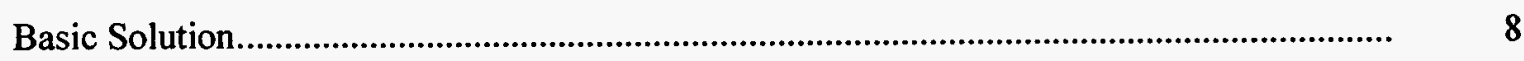

TANK FARM HEEL GROUTING_PRELIMINARY RESULTS............................................. $\quad 9$

Heel Displacement ....................................................................................................... 10

In Situ Heel Immobilization by Dry Grout Addition ........................................................... 10

Tank Farm Heel Grout Discussion .................................................................................

CONCLUSIONS, RECOMMENDATIONS, AND FUTURE STUDIES......................................... 15

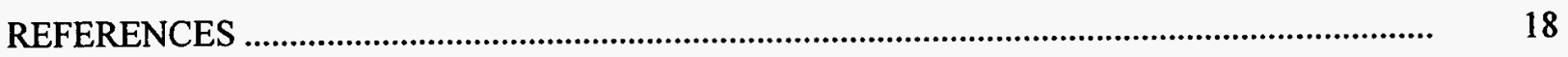

\section{FIGURE}

1. Effect of powder addition order on the compressive strength of grout..................................

\section{TABLES}

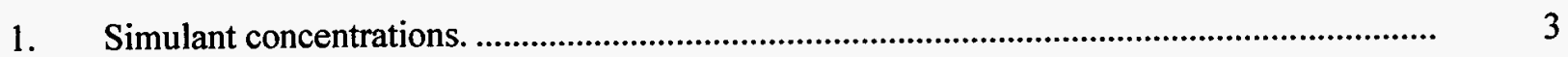

2. Denitration and grouting results for sodium-bearing waste simulants....................................

3. Leach results for sodium-bearing waste simulants................................................................ 4 
4. Average properties of grouted acidic simulants

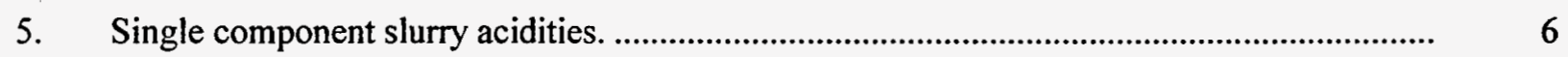

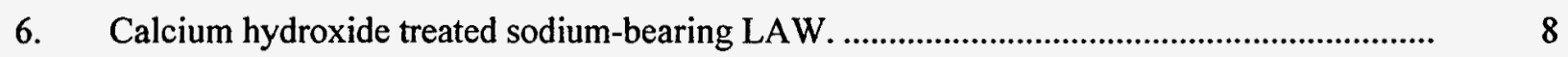

7. Basic grout formulations ( $25 \mathrm{wt} \%$ aqueous waste loading, liq./slds. $=0.4 \mathrm{~mL} / \mathrm{gm}$ )............. 9

8. Sodium hydroxide and calcium hydroxide treated sodium-bearing LAW grout..................... 9

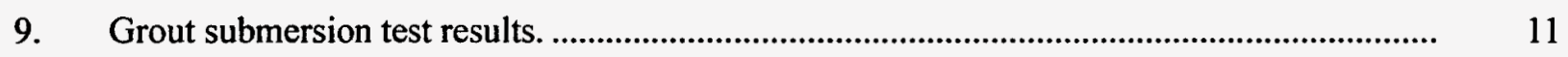

10. Parameters and results for in situ heel immobilization by dry grout addition.......................... 12

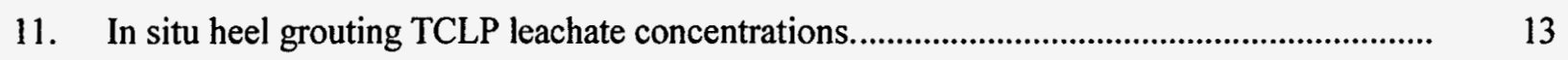

12. Estimated grout formulations to produce a cubic meter of grouted low-activity waste ......... 17 


\section{ACRONYMS}

Al LLW low-level waste derived from aluminum calcine

ASTM American Society for Testing and Materials

BFS blast furnace slag

CFR Code of Federal Regulations

Comp. Str. compressive strength

DOE U.S. Department of Energy

FA fly ash

ICPP Idaho Chemical Processing Plant

INEEL Idaho National Engineering and Environmental Laboratory

LAW low-activity waste

LLW low-level waste

Na LLW low-level waste derived from sodium-bearing waste

$\mathrm{NO}_{\mathrm{x}} \quad$ oxides of nitrogen

NRC U.S. Nuclear Regulatory Commission

PC portland cement

TCLP Toxicity Characteristic Leaching Procedure

UTS Universal Treatment Standards

Zr LLW low-level waste derived from zirconium calcine 


\section{NOMENCLATURE}

Blast Furnace Slag is a finely ground nonmetallic waste product developed in the manufacture of pig iron, consisting basically of a mixture of lime, silica, and alumina, the same oxides that make up portland cement, but not in the same proportions or forms.

Calcination is the process of converting a liquid to a solid product called calcine.

Cement refers to type I/II portland cement.

Fly Ash is a pozzolan of finely divided residue that results from the combustion of ground or powdered coal. Class $\mathrm{C}$ fly ash may contain $10 \%$ lime, has cementitious properties, and reacts with water to form a solid. Class $\mathrm{F}$ fly ash does not use water and aids in grout flow.

Grout is a mixture of portland cement, other powdered additives, waste, and water. It may contain finegrained sand and does not include large aggregate material. For this study, grouting is the process of solidifying and stabilizing low-level waste in cement based materials.

Leaching is the process whereby a liquid agent will dissolve hazardous materials within a waste mass and transport these materials through the mass and beyond. The most widely used laboratory leaching test is the TCLP (Toxic Characteristic Leaching Procedure) specified by the EPA in several regulations. For many treated and untreated wastes, the results of this test determine whether the EPA considers the material toxic or not.

Low-Activity Waste is low-level waste derived from the solvent extraction, ion exchange, and chemical extraction separation processes on the tank farm sodium-bearing waste and on the dissolved calcines.

Portland Cement is the product obtained by pulverizing clinker consisting essentially of hydraulic calcium silicates.

Pozzolan is a siliceous or siliceous and aluminous material that reacts with liquid calcium hydroxide in the cement gel to form compounds possessing cementitious properties.

Three-Way Blend is a 1:1:1 blend of portland cement, blast furnace slag, and coal fired power plant fly ash on a mass basis.

Solidification is the process of producing from liquid, sludge, or loose solids a more or less monolithic structure having some integrity. Occasionally, solidification may refer to the process that results in a soil-like material rather than a monolithic structure. Solidification does not necessarily reduce leaching of hazardous materials. However, when a waste is solidified, its mass and structure are altered, decreasing migration of solutions within the mass. 
Stabilization generally refers to a purposeful chemical reaction that has carried out to make waste constituents less leachable. This is accomplished by chemically immobilizing hazardous materials or reducing their solubility by a chemical reaction.

Water-to-cement ratio is defined as the mass of the water divided by the mass of the cements used (portland cement plus cement additives). In the case of the three way blends of portland cement, blast furnace slag, and fly ash, the mass of the water was divided by the total mass of the three cementing agents. The mass of the waste is not included in this calculation.

Waste form is the final product for long-term storage. This includes the solidified/stabilized waste as well as the container. The waste form must pass extensive qualification testing prior to release for storage.

Waste loading is the mass of the waste on a dry basis that is added to the mass of the waste solidification/stabilization additives, also on a dry basis. The mass of the waste reflects only the amount of original waste placed in the final grout. The mass of preconditioning additives or off-gas products are not used in the calculation.

Vitrify is the process of placing waste material in a glass form. This is a thermal process where the waste material is placed in a melter with glass beads or frit, then heated together, poured into a storage container, and cooled to a solid form.

$\mathrm{Vol}_{\text {grout }} / \mathrm{Vol}_{\text {sim }}$ is the ratio of the volume of grout produced from a given volume of the original liquid low-level waste volume. For a ratio of 4 , the volume of grout would be 4 times greater than the original volume of the liquid waste. If the ratio is less than 1.0 , the volume of grout would be less than the original liquid waste volume. An objective of the preconditioning and grouting processes is to optimize (reduce) this ratio; thus, reducing final repository costs based on volume. 


\section{IDAHO CHEMICAL PROCESSING PLANT LOW-LEVEL WASTE GROUT STABILIZATION DEVELOPMENT PROGRAM FY-97 STATUS REPORT}

\section{INTRODUCTION}

The High-Level Waste Program Plan for the Idaho Chemical Processing Plant (ICPP) calls for the sodium-bearing liquid waste in the tank farm to be separated into high-activity and low-activity radioactive wastes.' The calcine in the storage bins will be retrieved, dissolved in nitric acid, and separated. The small volume, high-activity waste will be vitrified and disposed in a geological repository. The large volume, low-activity waste (LAW) will be grouted and either returned to the tank farm vessels or disposed in drums. In addition to the LAW derived from separations, facility decontamination and the process equipment waste system will continue to generate low-level waste (LLW) liquids to be grouted. These decontamination and process equipment solutions are also a form of sodium-bearing waste. Further details of the grout program can be found in Section 4.5 of the High-Level Waste Program Plan. This research provides data on the various alternatives being proposed by the Department of Energy (DOE) High-Level Waste and Facilities Disposition Environmental Impact Statement.

During fiscal year 1997, two main tasks were worked. The first task was continued development of grout formulations to dispose of the sodium-bearing liquid waste from separations, facility decontamination, and process equipment waste. The second task was the development of a formulation to grout the tank farm vessel process residual heels. This second task was a new item added in the second quarter and is related to the closure of tank farm vessels. Once the sodium-bearing waste has been removed from the tanks, it is expected that 2 to 4 inches of liquid will remain on the tank floor $(2,500$ to 5,000 gallons). This heel will need to be stabilized in a solid form for tank closure.

The results are divided into three main sections. Section I discusses the grouting of thermally calcined, denitrated sodium-bearing LAW. Section II reports on the grouting of liquid sodium-bearing LAW by direct grouting (no pretreatment), partial neutralized $(\mathrm{pH}<3$ ) acidic liquid grouting, and fully neutralized $(\mathrm{pH}>11)$ basic liquid grouting. Section III notes the results of vessel heel solidification by cement powder addition and by premixed grout displacement.

The criteria for an acceptable grout formulation and wasteform are governed by the Department of Energy and augmented with guidelines from the U.S. Nuclear Regulatory Commission. These documents are Department of Energy Order 5820.2a, "Radioactive Waste Management," and the "Technical Position on Waste Form," published by the Low-Level Waste Management Branch of the U.S. Nuclear Regulatory Commission (NRC). ${ }^{2}$ The NRC guidelines are specifically directed at grouted wasteforms and contain definitive qualifications in the areas of compressive strength, leach resistance, thermal cycling, immersion testing, and irradiation. 


\section{GROUTING OF DENITRATED SOLID SODIUM-BEARING LAW}

Research on grouting sodium-bearing low-activity waste (LAW) has continued for about three years and a proposed process flowsheet and grout formulation have been developed. During this fiscal year, the grout formulation was "pushed" to increase waste loading and improve volume reduction. Additionally, alternative processes were explored to determine if simpler processes could be found that would decrease costs and improve waste loading and volume reduction.

Selection of a method to dispose of sodium-bearing waste is important as this is the type of waste will continue to be produced at the Idaho Chemical Processing Plant (ICPP) for several years to come. Currently, any facility decontamination (decon) solutions and process equipment waste (PEW) are collected and evaporated in the PEW evaporator. The overhead off-gas is condensed and disposed via the service waste system. The evaporator bottom solution is discharged to the vessels in the tank farm and is known as sodium-bearing waste. The majority of the sodium comes from the decontamination solutions. Since the tank farm is to be closed, the evaporator bottoms will need to be diverted to another storage tank pending grouting and disposal. The sodium-bearing waste is difficult to calcine due to agglomeration problems; thus, the separation processes are proposed to remove waste from the tank farm.

Simulants used in this study are noted in Table 1. The sodium-bearing LAW is the projected waste from the separations process. The tank farm heel simulant is the expected waste remaining in the tanks to be grouted for tank closure. In discussions with plant personnel, it was determined that vessel WM-186 currently contains a majority of decon/PEW evaporated wastes. As can be seen in Table 1, the decon/PEW is very similar to the sodium-bearing waste simulants tested in previous years, except for the acidity. With the denitration preconditioning step, the acidity is destroyed as well as the nitrates.

Denitration is the thermal calcination of the liquid waste at $650^{\circ} \mathrm{C}$ to produce a solid for grouting. The percent of nitrates destroyed is noted in Table 2 for sodium-bearing LAW with various additives. Denitration without additives is about $80 \%$ effective for nitrate destruction. The denitrated solids can be grouted up to 35 weight percent (wt\%) while maintaining strength ${ }^{3}$ and a volume reduction of about 5 . The grout also passed the thermal cycle test. The use of clay to promote denitration results in about $98 \%$ nitrate destruction, but the added clay sacrifices volume and waste loading while maintaining strength. The addition of aluminum compounds, such as aluminum hydroxide and aluminum nitrate, to the denitration process slightly reduced the efficiency rather improve it as was expected. Additional denitration and grouting tests were run where the grout formers slag and fly ash were added during denitration rather than in the grouting step. These solids were then grouted at $25 \mathrm{wt} \%$. The denitration efficiency again dropped as well as compressive strength and volume reduction.

One other test was completed where the liquid LAW was evaporated to dryness at $300^{\circ} \mathrm{C}$ and grouted at waste loadings from 7 to $35 \mathrm{wt} \%$. In each case the grout failed to set. It was noted that if the evaporated solids were rehydrated, the solution retained its acidity. It is postulated that the remaining high nitrate content and the acidity do not allow the grout to cure. Thus, simple evaporation to dryness is not recommended. It could be used as a step prior to thermal calcination, but not as a stand alone process. 
Table 1. Simulant concentrations.

\begin{tabular}{|c|c|c|c|}
\hline Species & $\begin{array}{c}\text { Sodium-Bearing AW } \\
\text { (molarity) }\end{array}$ & $\begin{array}{c}\text { WM-186 } \\
\text { Decon/PEW } \\
\text { (molarity) }\end{array}$ & $\begin{array}{c}\text { Tank Farm Heel } \\
\text { (molarity) }\end{array}$ \\
\hline $\mathrm{H}$ & $7.70 \mathrm{E}-01$ & $1.49 \mathrm{E}+00$ & $1.57 \mathrm{E}+00$ \\
\hline $\mathrm{Al}$ & 3.37E-01 & $3.50 \mathrm{E}-01$ & $6.39 \mathrm{E}-01$ \\
\hline As & $3.11 \mathrm{E}-05$ & - & - \\
\hline $\mathrm{Ba}$ & $3.21 \mathrm{E}-05$ & - & $6.10 \mathrm{E}-05$ \\
\hline B & $9.47 \mathrm{E}-03$ & $2.00 \mathrm{E}-02$ & $1.80 \mathrm{E}-02$ \\
\hline $\mathrm{Cd}$ & $1.47 \mathrm{E}-03$ & $1.70 \mathrm{E}-03$ & $2.76 \mathrm{E}-03$ \\
\hline $\mathrm{Ca}$ & 2.79E-02 & $6.30 \mathrm{E}-02$ & $5.27 \mathrm{E}-02$ \\
\hline $\mathrm{Cl}$ & $1.53 \mathrm{E}-02$ & $2.00 \mathrm{E}-02$ & $2.87 \mathrm{E}-02$ \\
\hline $\mathrm{Cr}$ & $1.95 \mathrm{E}-03$ & - & $3.71 \mathrm{E}-03$ \\
\hline Cs & $5.79 \mathrm{E}-10$ & $3.30 \mathrm{E}-06$ & $1.06 \mathrm{E}-05$ \\
\hline $\mathrm{F}$ & 3.63E-02 & $4.00 \mathrm{E}-02$ & $6.89 \mathrm{E}-02$ \\
\hline $\mathrm{Fe}$ & $1.16 \mathrm{E}-02$ & $1.80 \mathrm{E}-02$ & $2.20 \mathrm{E}-02$ \\
\hline $\mathrm{Pb}$ & 7.37E-04 & - & $1.43 \mathrm{E}-03$ \\
\hline $\mathrm{Mn}$ & 8.42E-03 & - & $1.22 \mathrm{E}-02$ \\
\hline $\mathrm{Hg}$ & $5.73 \mathrm{E}-04$ & - & $1.13 \mathrm{E}-03$ \\
\hline Mo & $3.68 \mathrm{E}-04$ & - & $6.37 \mathrm{E}-04$ \\
\hline $\mathrm{Ni}$ & 8.42E-04 & - & $1.64 \mathrm{E}-03$ \\
\hline $\mathrm{NO}_{3}$ & $2.67 \mathrm{E}+00$ & $2.93 \mathrm{E}+00$ & $5.17 \mathrm{E}+00$ \\
\hline $\mathrm{PO}_{4}$ & - & - & $1.40 \mathrm{E}-02$ \\
\hline K & $1.08 \mathrm{E}-01$ & $1.60 \mathrm{E}-01$ & $2.04 \mathrm{E}-01$ \\
\hline $\mathrm{Se}$ & $1.50 \mathrm{E}-05$ & 一 & - \\
\hline $\mathrm{Ag}$ & $1.21 \mathrm{E}-05$ & - & - \\
\hline $\mathrm{Na}$ & $1.10 \mathrm{E}+00$ & $9.60 \mathrm{E}-01$ & $1.89 \mathrm{E}+00$ \\
\hline $\mathrm{Sr}$ & & - & $5.10 \mathrm{E}-06$ \\
\hline $\mathrm{SO}_{4}$ & $2.63 \mathrm{E}-02$ & $3.30 \mathrm{E}-02$ & $5.04 \mathrm{E}-02$ \\
\hline $\mathrm{Zr}$ & $5.26 \mathrm{E}-04$ & - & $2.85 \mathrm{E}-03$ \\
\hline
\end{tabular}


Table 2. Denitration and grouting results for sodium-bearing waste simulants.

\begin{tabular}{|c|c|c|c|c|c|}
\hline $\begin{array}{c}\text { Denitration } \\
\text { Additives }\end{array}$ & $\begin{array}{c}\text { Denitration } \\
(\%)\end{array}$ & $\begin{array}{c}\text { Waste Loading } \\
(\mathrm{wt} \%)\end{array}$ & $\mathrm{Vol}_{\text {grout }} / \mathrm{Vol}_{\text {sim }}$ & $\begin{array}{l}28 \text { Day Comp. } \\
\text { Strength (psi) }\end{array}$ & $\begin{array}{c}\text { Thermal } \\
\text { Cycle (psi) }\end{array}$ \\
\hline None & 79.5 & 25.0 & 0.26 & 2,350 & 3,570 \\
\hline None & 79.5 & 35.0 & 0.18 & 810 & 510 \\
\hline Clay * & 97.8 & 9.2 & 0.43 & 2,380 & \\
\hline Clay * & 97.8 & 16.0 & 0.26 & 1,040 & \\
\hline $\mathrm{Al}(\mathrm{OH})_{3}$ & 75.1 & $* *$ & & & \\
\hline $\mathrm{Al}\left(\mathrm{NO}_{3}\right)_{3}$ & 76.1 & $* *$ & & & \\
\hline Slag & 65.7 & 25.0 & 0.29 & 1,630 & \\
\hline Fly ash & 71.5 & 25.0 & 0.27 & 1,530 & \\
\hline $\begin{array}{l}\text { Slag and } \\
\text { Fly ash }\end{array}$ & 74.3 & 25.0 & 0.28 & 1,580 & \\
\hline $\begin{array}{l}\text { Evaporation } \\
\text { at } 300^{\circ} \mathrm{C}\end{array}$ & 0 & 7 to 35 & 1.0 to 0.25 & $<50$ & \\
\hline $\begin{array}{l}* \text { FY }-96 \text { results } \\
* * \text { Not grouted }\end{array}$ & & & & & \\
\hline
\end{tabular}

Table 3. Leach results for sodium-bearing waste simulants.

\begin{tabular}{lcccc}
\hline $\begin{array}{c}\text { Hazardous } \\
\text { Element }\end{array}$ & $\begin{array}{c}\text { Universal } \\
\text { Treatment } \\
\text { Standards } \\
(\mu \mathrm{g} / \mathrm{mL})\end{array}$ & $\begin{array}{c}\text { Na LLW at 25\% } \\
\text { in 3-Way Blend } \\
(\mu \mathrm{g} / \mathrm{mL})\end{array}$ & $\begin{array}{c}\text { Na LLW at 25\% } \\
\text { with Clay in } \\
3-\text { Way Blend } \\
(\mu \mathrm{g} / \mathrm{mL})\end{array}$ & $\begin{array}{c}\text { Na LLW at 43\% } \\
\text { in High Slag Grout } \\
(\mu \mathrm{g} / \mathrm{mL})\end{array}$ \\
\hline Arsenic & $<5.0$ & 0.0180 & $*$ & $<0.10$ \\
Barium & $<7.6$ & 0.5863 & $*$ & 0.79 \\
Cadmium & $<0.19$ & 0.0125 & 0.1304 & $<0.050$ \\
Chromium & $<0.86$ & 0.5001 & 0.0780 & $<0.050$ \\
Lead & $<0.37$ & $<0.0352$ & 0.0799 & $<0.050$ \\
Mercury & $<0.20$ & $<0.0002$ & $<0.0004$ & $<0.0020$ \\
Nickel & $<5.0$ & 0.0337 & $*$ & $<0.050$ \\
Selenium & $<0.16$ & 0.0902 & $*$ & $<0.10$ \\
Silver & $<0.30$ & 0.0091 & $*$ & \\
$*$ Element not added to sample simulant & & & \\
\hline
\end{tabular}

Grout samples were subjected to the Toxicity Characteristic Leaching Procedure (TCLP). ${ }^{4}$ Table 3 notes that all of the grout samples passed the universal treatment standards. ${ }^{5}$ Thus, the 3-way blend grout formulation continues to be recommended. This blend consists of equal parts of portland cement, blast furnace slag, and coal-fired power plant fly ash. ${ }^{6-8}$ 


\section{GROUTING OF AQUEOUS SODIUM-BEARING LAW}

Low-activity aqueous sodium wastes may be grouted following dilution, concentration, and/or acid reduction without presolidifying the waste. A parametric scoping study was conducted to explore the effects of aqueous waste acidity, grout composition, and waste loading on the compressive strengths of the resulting grouts. Approximately one-third of the grout formulations containing hazardous metal salts were subjected to TCLP to determine if the grouts exhibit characteristic toxicity.

Three ranges of waste acidity were tested; namely, directly grouted solution $\left(\sim 0.77 \mathrm{NH}^{+}\right)$, partially neutralized acidic solution $(1.3 \leq \mathrm{pH} \leq 2.8)$, and basic solution $(11.9 \leq \mathrm{pH} \leq 12.1)$. Near neutral $\mathrm{pH}$ values for the simulant is undesirable because aluminum and iron precipitates form which (apparently) interfere with hydration of the cement, slag, and fly ash. Attempts to grout neutralized simulant were unsuccessful because the grout did not fully set, but remained plastic. The precipitates can be avoided when the $\mathrm{pH}$ is either less than 3 or greater than 11 .

\section{Direct Grouting}

Scoping tests were completed on grout formulations with a $25 \mathrm{wt} \%$ waste loading and various quantities of type $\mathrm{I} / \mathrm{II}$ portland cement (PC), blast furnace slag (BFS), and Class F fly ash (FA). The acidic simulant was diluted somewhat with water to provide a liquid to solids ratio of $0.4 \mathrm{~mL} / \mathrm{gm}$ and added to the preblended powders. The resulting "mud" was mixed for five minutes before placement in 2 -inch cubes for curing. In all cases, the acid reacted with the slag to evolve hydrogen sulfide gas. For each formulation, two cubes were produced. One produce cube was crushed after seven days of curing and another after 28 days to determine the compressive strengths. As grout cures, changes in crystalline speciation occur that cause an increase in compressive strength. The grout formed from directly grouted simulants, however, often exhibited atypical behavior. Four of the nine formulations tested showed a negative trend, where the compressive strength after 28 days of curing was less than the strength measured after seven days of curing. In general, a high fly ash content in the powder blend suppresses the compressive strength, especially with limited curing time.

Two samples were submitted for TCLP analysis to determine whether the hazardous constituents were adequately immobilized. The grout formulations were both $25 \mathrm{wt} \%$ simulant and with PC:BFS:FA blends of 1:1:1 and 1:6:1, respectively. Both samples returned results below the Universal Treatment Standard (UTS) limits for all characteristically toxic metals that had been included in the simulant.

\section{Acidic Solution}

A stronger grout is produced if the simulated waste is partially neutralized with a sodium hydroxide solution prior to the powder additions than if the simulant is grouted directly. Partial neutralization allows the grout to cure normally (i.e., increasing in compressive strength with time). Only one formulation out of 40 showed the anomalous behavior of decreasing strength after 28 days of curing when compared with the strength after seven days of curing. This anomalous grout was formed by adding the acidic simulant to preblended solids with a PC:BFS:FA mass ratio of $1: 1: 1$ and $25 \mathrm{wt} \%$ simulant. The 28-day compressive strength of this grout formulation was nearly $4,300 \mathrm{psi}$, more than eight times the minimum requirement.

The formulations for grouting acidic simulants ranged in composition from 1-6 parts slag (by weight), 1-3 parts fly ash, and all with 1 part cement. Waste loadings ranged from a low of $25 \mathrm{wt} \%$ 
simulant with a liquid-to-solids ratio of $0.40 \mathrm{~mL} / \mathrm{gm}$ to $33 \mathrm{wt} \%$ with concentrated simulant and a ratio of $0.46 \mathrm{~mL} / \mathrm{gm}$.

Compressive strengths were nearly as good for grout with waste loadings of $31 \mathrm{wt} \%$ (concentrated simulant) as for the grout with $25 \mathrm{wt} \%$ simulant. A marked decrease in compressive strength was noted for grout with $33 \mathrm{wt} \%$ (concentrated simulant) waste loadings. With any waste loading, the 28-day compressive strength was inversely proportional to the amount of fly ash in the formulation. At $25 \mathrm{wt} \%$ waste loadings, the compressive strengths increased with increasing slag content, but the converse was true for the $33 \mathrm{wt} \%$ (concentrated simulant) grout formulations. With the higher waste loadings, the quantity of acid that must be destroyed is larger, but proportionally less cement is available to react with the acid when high slag formulations are used. Average properties of the acidic grout formulations are given in Table 4.

When grouting the simulant with or without partial neutralization, the acid in the simulant reacts with the slag, fly ash, and cement to varying degrees. Acidities were measured on three slurries after adding a single powder to the simulated waste. The extent of acid destruction capacity for each solid is as follows: PC > BFS > FA (see Table 5, below). Because the slag reacts with the acid to release hydrogen sulfide, one might hypothesize that the addition order of the slag, fly ash, and cement would have a profound effect on the compressive strength and the leachability of heavy metals from the grout. To test the hypothesis, 13 sample sets were prepared from a common waste simulant solution, using identical waste loadings (30 wt \%), liquid-to-solid ratios $(0.40 \mathrm{~mL} / \mathrm{gm})$, and powder ratios

(1:3:1 PC:BFS:FA). These are comparable to grouting the Na-LAW without concentration or dilution, except for the sodium hydroxide solution that was added to partially neutralize the simulant. All components were weighed out to reduce the measurement error to no more than $0.1 \%$. The grout forming powders were added to the simulant individually and/or in binary blends to ascertain the effects of the addition order on the grout properties. After each powder addition the slurry was mixed for about five minutes before subsequent powder additions or placement in the molds. The 28-day compressive strengths ranged from 4,800 psi to 8,800 psi (Figure 1) and appear to be independent of the total mixing time for a given sample.

Table 4. Average properties of grouted acidic simulants.

\begin{tabular}{lcccc}
$\begin{array}{c}\text { Na-LAW } \\
\text { Simulant }\end{array}$ & $\begin{array}{c}\text { Waste } \\
\text { Loading } \\
(\mathrm{wt} \%)\end{array}$ & $\begin{array}{c}\text { Avg. } \\
\text { Cube } \\
\text { Density } \\
\left(\mathrm{gm} / \mathrm{cm}^{3}\right)\end{array}$ & $\begin{array}{c}\text { 28-day Comp. } \\
\text { Strengths } \\
(\mathrm{psi})\end{array}$ & $\mathrm{Vol}_{\text {grout }} / \mathrm{Vol}_{\text {sim }}$ \\
\hline $\begin{array}{l}\text { Unneutralized } \\
\text { Acidic }\end{array}$ & 25 & 1.86 & $1,640-6,850$ & 2.4 \\
$\begin{array}{l}1.6 \leq \mathrm{pH} \leq 2.8) \\
\begin{array}{l}\text { Acidic } \\
(\mathrm{pH}=1.3)\end{array}\end{array}$ & 25 & 1.89 & $280-7,850$ & 2.4 \\
$\begin{array}{l}\text { Acidic } \\
(1.2 \leq \mathrm{pH} \leq 1.9)\end{array}$ & 30 & 1.96 & $4,800-8,820$ & 1.9 \\
$\begin{array}{l}\text { Acidic } \\
(1.3 \leq \mathrm{pH} \leq 1.4)\end{array}$ & $\begin{array}{c}\text { (conc.) } \\
\text { (conc.) }\end{array}$ & 1.95 & $70-6,930$ & 1.6 \\
\hline
\end{tabular}


Table 5. Single component slurry acidities.

Component(s)

$\mathrm{pH}$ of

Solution/Slurry

Partially neutralized simulant

Portland cement + simulant

(111 gm/ $214 \mathrm{~mL})$

9.8

Blast furnace slag + simulant

(333 gm/ $214 \mathrm{~mL})$

8.0

Class F fly ash + simulant

$(111 \mathrm{gm} / 214 \mathrm{~mL})$

3.2

When ranked by compressive strength, the top five formulations were produced by adding the slag before the cement, five of the weakest six formulations were produced by adding the cement prior to the slag, and the remaining three formulations involved preblended admixtures of cement and slag. Formulations that included fly ash in the initial powder addition, either solo or as a binary mixture, dominated the mid-range compressive strength values.

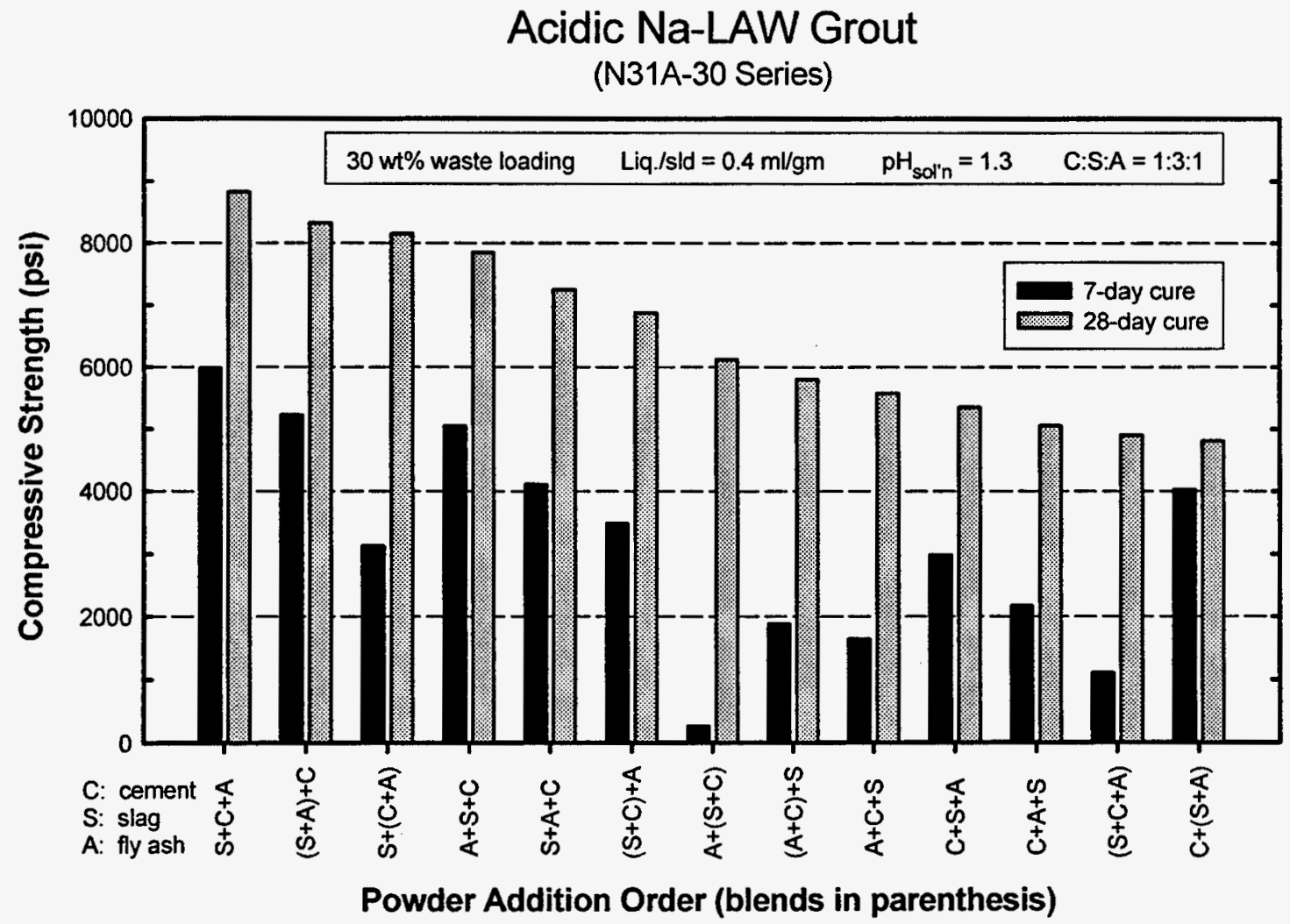

Figure 1. Effect of powder addition order on the compressive strength of grout. 
TCLP data for the 13 sample sets found detectable levels of barium leaching from all samples, but the concentrations in the leachates were approximately one-tenth of the UTS limit. Only one formulation leached a quantifiable amount of mercury from the grout at $0.0031 \mathrm{mg} / \mathrm{L}$ or one-eighth of the UTS limit for mercury. All others were less than $0.002 \mathrm{mg} / \mathrm{L}$ of mercury. No quantifiable amounts of arsenic, cadmium, chromium, lead, nickel, selenium, or silver were measured and all were below their respective UTS limits.

Another method of partial neutralizing the sodium simulant was tried with solid calcium hydroxide. This was done at waste loadings of 17 to $54 \mathrm{wt} \%$. Calcium hydroxide was added at the rate of 1 mole calcium hydroxide to 2 mole of hydrogen ion (acid). This results in a pH of 2 to 3 and leaves undissolved/unreacted calcium hydroxide in the solution. The solution was grouted with the three-way cement blend. As can be noted in Table 6, the compressive strength drops off rapidly with increasing waste loading. At a waste loading of about $30 \mathrm{wt} \%$ is a break even point in the volume in vs. volume out. The 17 to $42 \mathrm{wt} \%$ samples were submitted for TCLP and all the results were less than detection limits. The two high loading samples did not set up and were not leach tested.

\section{Basic Solution}

Several grout formulations were prepared with sodium LAW simulant that was treated with sodium hydroxide to produce a caustic solution. Data for this series were sorted by their 28 -day compressive strengths and are given in Table 7. It can be observed that slag contributes more to the compressive strength than does fly ash. This is observed by comparing the formulations with identical mass fractions of portland cement and by comparing samples with constant cement:slag ratios. Only the formulation with equal parts of cement, slag, and fly ash lost strength after curing for seven days. Grout formulations containing a large fraction of fly ash exhibit higher compressive strengths when grouting basic wastes than acidic wastes. The converse is true for low-ash formulations.

Table 6. Calcium hydroxide treated sodium-bearing LAW.

\begin{tabular}{lccc}
\hline $\begin{array}{c}\text { Waste Loading } \\
(\mathrm{wt} \%)\end{array}$ & $\begin{array}{c}\text { Cube Density } \\
\left(\mathrm{gm} / \mathrm{cm}^{3}\right)\end{array}$ & $\begin{array}{c}\text { 28-day Crush } \\
\text { Strength }(\mathrm{psi})\end{array}$ & Vol $_{\text {grout }} / \mathrm{Vol}_{\text {sim }}$ \\
\hline 17.2 & 1.91 & 8310 & 1.56 \\
25.5 & 1.87 & 4770 & 1.10 \\
33.7 & 1.83 & 1370 & 0.86 \\
42.0 & 1.75 & 270 & 0.73 \\
48.1 & $*$ & $*$ & 0.67 \\
53.9 & $*$ & $*$ & 0.65 \\
\hline Sample did not set up & & &
\end{tabular}


Table 7. Basic grout formulations ( $25 \mathrm{wt} \%$ aqueous waste loading, liq. $/ \mathrm{slds} .=0.4 \mathrm{~mL} / \mathrm{gm}$ ).

\begin{tabular}{lcccc}
\hline $\begin{array}{c}\text { Powder Ratio } \\
\text { Cement:Slag:Ash }\end{array}$ & $\begin{array}{c}\text { Simulant } \\
\mathrm{pH}\end{array}$ & $\begin{array}{c}\text { Cube Density } \\
\left(\mathrm{gm} / \mathrm{cm}^{3}\right)\end{array}$ & $\begin{array}{c}\text { 28-day Crush } \\
\text { Strength }(\mathrm{psi})\end{array}$ & Vol $_{\text {grout }} / \mathrm{Vol}_{\text {sim }}$ \\
\hline $1: 4: 1$ & 12.0 & 1.95 & 5580 & 2.29 \\
$1: 2: 1$ & 11.9 & 1.87 & 5050 & 2.38 \\
$1: 6: 3$ & 11.9 & 1.94 & 4120 & 2.30 \\
$1: 6: 2$ & 11.9 & 1.92 & 4000 & 2.32 \\
$1: 6: 1$ & 12.1 & 1.97 & 3980 & 2.26 \\
$1: 4: 3$ & 11.9 & 1.93 & 3220 & 2.31 \\
$1: 2: 3$ & 11.8 & 1.89 & 2570 & 2.36 \\
$1: 2: 2$ & 11.9 & 1.90 & 2500 & 2.35 \\
$1: 1: 1$ & 11.9 & 1.98 & 2170 & 2.25 \\
$1: 4: 2$ & 11.9 & 1.90 & 2160 & 2.35 \\
\hline
\end{tabular}

A second type of basic grout was prepared following a formulation developed by AEA Technologies of the United Kingdom under a DOE international contract. ${ }^{9}$ The formulation preconditions the waste to a $\mathrm{pH}$ of 12 prior to grouting with 1 part portland cement and 9 parts slag. The liquid waste simulant is added to sodium hydroxide and allow to sit for three days. Next, calcium hydroxide is added and allowed to sit another day. The rest period allows reactions to reach chemical equilibrium to avoid precipitation. Finally, the basic solution is cemented with portland cement and slag and some additional calcium hydroxide. This produces a waste loading of $43.3 \mathrm{wt} \%$ and the 28 day strength is about $920 \mathrm{psi}$ (Table 8). By TCLP, all of the hazardous metals were below detectability, except barium at 0.79 micrograms per milliliter, which is well below the limit (Table 3 ). For this formulation the volume increases by 1.55 , i.e., one liter of waste will produce 1.55 liters of grouted waste. The strength reduced to 810 psi after thermal cycle tests. AEA Technology grouted a 55 gallon drum of our sodium LAW simulant and found similar results. The grout formulation looks promising in that minimum strengths are met while achieving a high waste loading; however, the long-term durability ( 90 day immersion test) needs to be evaluated. If volume is not a driver, this formulation appears favorable.

\section{TANK FARM HEEL GROUTING — PRELIMINARY RESULTS}

As a part of the future closure of the tank farm, remaining heels will require removal and/or in situ immobilization. Two options that would be relatively inexpensive and pose minimal risk to worker health and safety were identified for initial immobilization testing. The first involves displacing the heel solutions with fluid grout addition to the tanks, forcing the solutions towards the existing jet transfer lines for subsequent removal. The waste solutions would then be treated in existing facilities (i.e., HLW

Table 8. Sodium hydroxide and calcium hydroxide treated sodium-bearing LAW grout.

\begin{tabular}{ccccc}
\hline $\begin{array}{c}\text { Waste Loading } \\
(\mathrm{wt} \%)\end{array}$ & $\begin{array}{c}\text { Cube Density } \\
\left(\mathrm{gm} / \mathrm{cm}^{3}\right)\end{array}$ & $\begin{array}{c}\text { 28-day Crush } \\
\text { Strength }(\mathrm{psi})\end{array}$ & $\begin{array}{c}\text { Thermal } \\
\text { Cycle }(\mathrm{psi})\end{array}$ & $\mathrm{Vol}_{\text {grout }} / \mathrm{Vol}_{\text {sim }}$ \\
\hline 43.4 & 1.63 & 920 & 810 & 1.55 \\
\hline
\end{tabular}


evaporator and NWCF calciner). The second option involves adding dry grout powders to the tank heels to achieve in-place immobilization. Although the tank heels do contain a significant amount of undissolved solids that are potentially very high in radionuclide content, it is assumed for this testing that their presence will not impact either grouting method.

Adding water to the tank heels to dilute them, followed by removing the excess solution to the original heel levels, would be reasonable process steps to achieve acceptable tank farm heel immobilization using existing equipment. Thus, different degrees of heel dilution have been incorporated into the testing for both treatment options defined above.

\section{Heel Displacement}

All heel displacement tests were performed using nontoxic tank farm waste simulant, and grout made with equal weight percentages of portland cement, blast furnace slag, and Type F fly ash (three-way blend). The testing consisted of a pan test and a submersion test. The pan test involved actual displacement of waste simulant in a bake pan with fluid grout. The submersion test involved submerging partially cured ( 24 hours) grout samples, in solutions representing tank farm waste at different degrees of dilution or neutralization, for extended time periods ( 15 and 40 days, respectively). Both tests were performed to determine the effects the grout and simulant have on the other.

Results of the pan test showed that the fluid grout did cure and harden when used to displace the heel solution. However, the grout did remain soft at the interface area with the acidic solution. The grout slowly reacted with the solution and decomposed at the interface area. After three days of exposure, a significant amount of solid had sloughed at the interface and settled at the pan bottom. After 11 days of exposure, significant further grout decomposition had occurred and a considerably larger quantity of solids had settled to the pan bottom. The solution appeared to be partially gelled with a thin crystalline solid sheet (assumed aluminum hydroxide) covering the solution surface. The solution $\mathrm{pH}$ remained $<2$.

Test results for the submersion test are presented in Table 9. These results verify that grout will decompose over time when exposed to acidic solution. Additionally, the effects of the acid exposure penetrate the grout beyond the immediate interface area and ultimately are detrimental to the wasteform strength.

\section{In Situ Heel Immobilization by Dry Grout Addition}

The dry grout addition tests were performed with tank farm simulant that included average tank farm waste concentrations of toxic metals. Dry grout addition testing involved the preparation of two similar sets of grout samples, allowing each set to cure for a specific time period, performing compression strength tests on the samples, and performing TCLP analysis for each sample type. The sample curing periods for Tests 1 and 2 were 36 days and 55 days, respectively. The grout samples for each test set differed in levels of tank farm waste simulant dilution or neutralization. 
Table 9. Grout submersion test results.

\begin{tabular}{|c|c|c|c|c|c|c|}
\hline \multicolumn{2}{|c|}{$\begin{array}{l}\text { Submersion } \\
\text { Solution* }\end{array}$} & \multicolumn{2}{|c|}{$\begin{array}{l}\text { Compressive Strength (psi) } \\
\text { Following Submersion }\end{array}$} & \multicolumn{3}{|c|}{ Sample Weight $(\mathrm{g})^{* *}$} \\
\hline & & $\begin{array}{c}\text { 15-Day } \\
\text { Submersion }\end{array}$ & $\begin{array}{c}\text { 40-Day } \\
\text { Submersion }\end{array}$ & Before & After & $\begin{array}{c}\text { Weight } \\
\text { Change } \\
(\%) \\
\end{array}$ \\
\hline \multicolumn{2}{|c|}{$\begin{array}{l}100 \% \text { waste } \\
\text { simulant }\end{array}$} & 1,090 & 1,220 & 241.5 & 188.0 & -22.2 \\
\hline \multicolumn{2}{|c|}{$\begin{array}{l}50 \% \text { waste } \\
\text { simulant }\end{array}$} & 2,070 & 3,000 & 237.9 & 224.0 & -5.8 \\
\hline \multicolumn{2}{|c|}{$\begin{array}{l}25 \% \text { waste } \\
\text { simulant }\end{array}$} & 5,700 & 4,880 & 241.5 & 240.0 & -0.6 \\
\hline \multicolumn{2}{|c|}{$\begin{array}{l}12.5 \% \text { waste } \\
\text { simulant }\end{array}$} & 6,350 & 6,770 & 238.5 & 244.0 & +2.3 \\
\hline \multicolumn{2}{|c|}{ Water } & $2,980 * * *$ & 7,980 & 240.7 & 246.1 & +2.2 \\
\hline \multicolumn{2}{|c|}{$\begin{array}{l}\text { Waste } \\
\text { simulant } \\
\text { neutralized } \\
\text { to } \mathrm{pH} 2\end{array}$} & 1,900 & 1,750 & 237.5 & 222.8 & -6.2 \\
\hline \multicolumn{2}{|c|}{$\begin{array}{l}\text { Waste } \\
\text { simulant } \\
\text { neutralized } \\
\text { to } \mathrm{pH} 10\end{array}$} & $6,380^{\#}$ & 5,730 & 242.2 & 251.5 & +3.8 \\
\hline \multicolumn{2}{|c|}{ Control ${ }^{\#}$} & $6,380^{\#}$ & 7,010 & 241.5 & 238.9 & -1.1 \\
\hline$*$ & \multicolumn{6}{|c|}{ Balance of percentages is water. } \\
\hline ** & \multicolumn{6}{|c|}{$\begin{array}{l}\text { The before and after sample weight measurements were taken as a part of the } 40 \text {-day test, prior to the } \\
\text { submersion step and following the drying step after retrieval from submersion, respectively. }\end{array}$} \\
\hline$* * *$ & \multicolumn{6}{|c|}{ This low reading is likely the result of a faulty sample. } \\
\hline \# & \multicolumn{6}{|c|}{$\begin{array}{l}\text { For the } 15 \text {-day submersion test samples, the compression strength apparatus was set on low range. This } \\
\text { reading is the maximum measurement for this range. }\end{array}$} \\
\hline \#\# & \multicolumn{6}{|c|}{ Grout sample was enclosed cured, without any submersion. } \\
\hline
\end{tabular}

Each sample was prepared in a 2 -inch cube plastic mold by first adding enough liquid (tank farm simulant at different levels of dilution or neutralization) to ultimately achieve a liquid-to-solid weight ratio of approximately $30 \%$, and "spooning" the dry, three-way blend grout powder on top. Excess dry grout powder was scraped off to achieve a level surface at the mold open end. Test parameters and compression test results are presented in Table 10. 
Table 10. Parameters and results for in situ heel immobilization by dry grout addition.

\begin{tabular}{|c|c|c|c|c|}
\hline $\begin{array}{c}\text { Liquid } \\
\text { Composition* }\end{array}$ & $\begin{array}{c}\text { Waste Wt } \% \\
\text { (Test } 1 / \text { Test 2) }\end{array}$ & $\begin{array}{c}\text { Volume } \\
\text { Change } \\
\text { Factor** } \\
\text { (Test } 1 / \text { Test 2) }\end{array}$ & $\begin{array}{c}\text { Density }\left(\mathrm{g} / \mathrm{cm}^{3}\right) \\
(\text { Test } 1 / \text { Test } 2)\end{array}$ & $\begin{array}{c}\text { Compressive } \\
\text { Strength (psi) } \\
\text { (Test 1/Test 2) }\end{array}$ \\
\hline $\begin{array}{l}100 \% \text { waste } \\
\text { simulant }\end{array}$ & $35.3 / 36.3$ & $0.37 / 0.37$ & $1.30 / 1.26$ & $150 / 100$ \\
\hline $\begin{array}{l}50 \% \text { waste } \\
\text { simulant }\end{array}$ & $16.4 / 16.3$ & $0.18 / 0.18$ & $1.40 / 1.40$ & $310 / 370$ \\
\hline $\begin{array}{l}25 \% \text { waste } \\
\text { simulant }\end{array}$ & $7.8 / 7.5$ & $0.09 / 0.09$ & $1.47 / 1.52$ & $800 / 860$ \\
\hline $\begin{array}{l}12.5 \% \text { waste } \\
\text { simulant }\end{array}$ & $3.8 / 3.8$ & $0.05 / 0.05$ & $1.54 / 1.54$ & $680 / 440$ \\
\hline Water & $0 / 0$ & $\mathrm{Na} / \mathrm{na}$ & $1.63 / 1.65$ & $1,170 / 670$ \\
\hline $\begin{array}{l}\text { Waste simulant } \\
\text { neutralized to } \\
\mathrm{pH}<2\end{array}$ & $33.8 / 33.0$ & $0.34 / 0.34$ & $1.24 / 1.26$ & $140 / 190$ \\
\hline $\begin{array}{l}\text { Waste simulant } \\
\text { neutralized to } \\
\text { pH } 5\end{array}$ & $30.1 / 31.4$ & $0.31 / 0.31$ & $1.29 / 1.24$ & $210 / 230$ \\
\hline $\begin{array}{l}\text { Waste simulant } \\
\text { neutralized to } \\
\text { pH } 10\end{array}$ & $--/ 30.9$ & $--/ 0.30$ & $--/ 1.21$ & $--/ 100$ \\
\hline \multicolumn{5}{|c|}{$\begin{array}{l}\text { Balance of percentages is water. } \\
\text { Based on a tank farm waste solution specific gravity of } 1.24\end{array}$} \\
\hline
\end{tabular}

TCLP leach tests were performed on the crushed grout fragments from each of the first set of in situ grouting samples (Test 1). The results of these leachability tests are presented in Table 11. A significant amount of precipitate had formed in both samples that had been partially neutralized prior to adding the dry grout powder. These precipitates were forced to the bottom of the sample cube mold upon the powder addition, ultimately forming two distinct solid layers; the solidified grout at the top and the precipitate at the bottom. For these two samples, separate TCLP analysis was done for each solid layer, as indicated in Table 11.

Leachate from all tests showed hazardous constituent concentrations well below the specified limits. Even the nongrouted precipitate layers of the partially neutralized test samples failed to produce leachate containing hazardous elements at concentrations of concern. 
Table 11. In situ heel grouting TCLP leachate concentrations.

\begin{tabular}{|c|c|c|c|c|c|c|}
\hline $\begin{array}{l}\text { Grout Sample } \\
\text { Liquid } \\
\text { Composition* }\end{array}$ & $\begin{array}{l}\text { Waste } \\
\text { Loading } \\
\text { (wt\%) }\end{array}$ & $\begin{array}{c}\mathrm{Hg} \\
(\mu \mathrm{g} / \mathrm{mL})\end{array}$ & $\begin{array}{c}\mathrm{Pb} \\
(\mu \mathrm{g} / \mathrm{mL})\end{array}$ & $\begin{array}{c}\mathrm{Cd} \\
(\mu \mathrm{g} / \mathrm{mL})\end{array}$ & $\begin{array}{c}\mathrm{Cr} \\
(\mu \mathrm{g} / \mathrm{mL})\end{array}$ & $\begin{array}{c}\mathrm{Ni} \\
(\mu \mathrm{g} / \mathrm{mL})\end{array}$ \\
\hline $\begin{array}{l}100 \% \mathrm{SBW} \\
\text { simulant }\end{array}$ & 35.3 & ND & ND & ND & 0.0043 & 0.0076 \\
\hline $\begin{array}{l}50 \% \text { SBW } \\
\text { simulant }\end{array}$ & 16.4 & ND & ND & ND & 0.0045 & ND \\
\hline $\begin{array}{l}25 \% \text { SBW } \\
\text { simulant }\end{array}$ & 7.8 & ND & ND & ND & ND & ND \\
\hline $\begin{array}{l}12.5 \% \mathrm{SBW} \\
\text { simulant }\end{array}$ & 3.8 & ND & ND & ND & ND & ND \\
\hline Water & 0 & ND & ND & ND & 0.0050 & ND \\
\hline $\begin{array}{l}\text { SBW simulant } \\
\text { neutralized to } \\
\mathrm{pH}<2 \\
\text { Grout (Top) } \\
\text { Layer }\end{array}$ & 33.8 & ND & ND & ND & 0.0051 & ND \\
\hline $\begin{array}{l}\text { SBW simulant } \\
\text { neutralized to } \\
\mathrm{pH}<2 \\
\text { Precipitate } \\
\text { (bottom) layer }\end{array}$ & 33.8 & ND & ND & ND & 0.0083 & ND \\
\hline SBW simulant & 30.1 & ND & ND & ND & 0.0119 & ND \\
\hline \multicolumn{7}{|l|}{$\begin{array}{l}\text { Neutralized to } \\
\text { pH } 5 \\
\text { Grout (top) } \\
\text { layer }\end{array}$} \\
\hline $\begin{array}{l}\text { Na simulant } \\
\text { neutralized to } \\
\text { pH } 5 \\
\text { Precipitate } \\
\text { (bottom) layer }\end{array}$ & 30.1 & ND & ND & ND & 0.0048 & ND \\
\hline $\begin{array}{ll}* & \text { Balance } \\
\text { ND } & \text { Not Dete }\end{array}$ & $\begin{array}{l}\text { rcentages i } \\
\text { - Below a }\end{array}$ & ticer & imits. & & & \\
\hline
\end{tabular}




\section{Tank Farm Heel Grout Discussion}

From the test results presented above, several generalized initial conclusions have been drawn. These are listed and discussed below.

1. Tank farm heel removal could be accomplished by displacing the solution with fluid grout and forcing it to the existing jet transfer line for each tank. However, the heel solution must be transferred out of the tank immediately, unless it is significantly diluted with water prior to grout addition. Many more reasonable scenarios for removing the tank heel can be developed using grout displacement and water dilution. For example, for an individual tank, adding water to double the volume (approximately 10,000 gallon), jetting the excess solution out using existing equipment, and repeating this process one additional time, would result in a heel that contains only $25 \%$ of the original waste solution. Grout could then be added to fill the tank to near the jet transfer line level, with the elevated solution also jetted out. Additional grout could then be poured in at the end of the tank opposite the transfer line to "push" any remaining solution to the line for removal. A final step might be to drop dry grout powder around the transfer line to solidify the small volume of remaining solution. This process would provide the removal of nearly all of the tank heel without any major changes to existing equipment. The final grout in the tank would be little over a foot deep, strong, and virtually free of contaminants. Removed diluted heel solutions could easily be treated using existing facilities (HLW evaporator, NWCF calciner).

2. 2. Heel neutralization should not be included as a part of either heel displacement or in situ grouting. Without mechanical mixing, concentrated hydroxide solutions do not readily disperse when added to heel solutions. Partial neutralization (to $\mathrm{pH}>2$ ) provides less reduction in grout degradation than does one $100 \%$ dilution (to $50 \%$ original waste solution). Partial neutralization also results in some precipitate formation. Although waste solution fully neutralized $(\mathrm{pH}>7$ ) has little or no impact on displacement grout quality, a significant amount of flocculent precipitate does result. This precipitate will be difficult to remove from the tanks by displacement and no facilities exist at the ICPP for the treatment of radioactive alkaline precipitates. Precipitate formed prior to in situ grouting without mixing will be pushed to the bottom of the respective tank upon addition of the dry grout powder and be trapped between the solid grout and the tank bottom. The majority of the hazardous and radioactive constituents will not be in an immobilized form and the compression strength of the total solid mass will be well below minimum acceptable limits.

3. Dry grout addition to the tank farm heels, without mixing, results in a grout with very poor compression strength. Although compression strength generally improves as the waste solution is further diluted, a grout with compression strengths consistently above the minimum allowed for low-level waste immobilization ( $500 \mathrm{psi}$ ) cannot be guaranteed, regardless of the dilution factor. This is due to inconsistencies in the grout from the powder addition, off-gassing, etc. The two samples prepared with dry grout addition to water demonstrate the extreme differences in compression strength that can occur for no apparent reason (Test 1 results nearly double that of Test 2). The poor quality of grout made with dry powder addition is further demonstrated by the fact that grout produced by active mixing of the same ingredients typically has compression strengths seven times that of the best sample from dry grout addition testing. 
4. The heel solution in each tank must be characterized, particularly for both the quantity and composition of the undissolved solids. It is likely that water dilution of the heels will result in minimal removal of these solids. Heel displacement with grout will result in limited mixing of the solids with the grout. Dry grout powder addition will result in the undissolved solids not being immobilized, i.e., trapped between the upper grout layer and the tank bottom.

\section{CONCLUSIONS, RECOMMENDATIONS, AND FUTURE STUDIES}

Preconditioning of the sodium-bearing low-activity waste prior to grouting has been shown to be a necessity. This can take the form of thermal calcination and denitration, reducing the acidity, or rendering the waste chemically basic. The viability of grouting calcined or denitrated solid waste simulants has been demonstrated by laboratory studies conducted over the past three years. Grouting of acidic and basic aqueous simulants has been introduced this year to the development program and lacks sufficient maturity to determine its viability.

Denitration and solidification process is done by thermal calcination at $650^{\circ} \mathrm{C}$. Studies of the process with and without additives were completed. Previously clay was used. This year aluminum compounds were tried. The aluminum compounds did not result in higher denitration efficiencies than the waste treated without any additives. As noted in last year's report, the clay improves denitration, but adds significant volume and needs excess water for grouting. Again, the results show that denitration without additives is the preferred denitration method.

Grouting of the denitrated solid waste continues to produce a viable grout product. The grout meets compressive strength and leach requirements and significantly reduces the volume of the grout. Waste loading can go as high as $35 \mathrm{wt} \%$ of the denitrated solids and meet minimum stability requirements. It is estimated that $30 \mathrm{wt} \%$ loading will allow for operational tolerances (to be studied in FY-98). Initial thermal cycling tests have proved satisfactory. In the case of $25 \mathrm{wt} \%$ grout, the strength actually increased after thermal cycling.

Denitration is energy intensive and requires an extensive off-gas system, but is the best method found to date for reducing waste volume. During FY-98, the long-term durability of the denitrated sodium-bearing LAW will be studied through continued thermal cycling and immersion tests. Additionally, grout properties will be studied, such as set time, cure rate, heat of hydration, viscosity, density, etc.

It was determined that the sodium-bearing LAW could be grouted by controlling the $\mathrm{pH}$ of the waste solution and increasing the slag content. The waste can be grouted at $1<\mathrm{pH}<3$. This can be done by adding sodium hydroxide to partially neutralize the acidity and then adding slag to the solution prior to the cement powder. It was found that this order of mixing was critical in forming a much stronger grout. Apparently, the slag neutralizes the waste to allow the portland cement to provide the initial set. If the portland cement is added first or as a mixed blend, the acidity attacks the portland cement for neutralization and there is insufficient cement for THE initial cure. The remainder of the slag and fly ash react later in the cure process and provide higher strengths. This process produces high strength grouts with waste loadings that increase the waste volume to about $11 / 2$ to 2 times the original volume, which is much better than the 3 to 4 volume increase with diluted waste in the 3 -way blend. The short-term results look promising, but the long-term tests have not been completed and are scheduled for FY-98. 
The AEA Technologies grout formulation, where the waste is completely basic $(\mathrm{pH}=12)$, also shows promise. The waste loading is maximized at $43 \%$ and results in a volume increase about $11 / 2$ times the original volume. The samples passed the thermal cycle test and a 90 -day immersion test is in progress. The immersed sample cubes do not show any cracking to date (60 days). This grout formulation is intended for in-drum mixing as the wet grout is rather viscose. If the grout is to go to the tank farm for disposal, a more fluid grout formulation would be required for this process.

Current cost projections include the cost of disposal and storage as the dominant cost factor. Thus disposal volume is a critical driver. If the grout goes to drums for later disposal, preliminary cost estimates show the denitration process to be cost-effective due to the greatest volume reduction. This includes adjustments for the higher process energy costs and off-gas treatment. However, if volume ceases to be a driver, the alternative processes of liquid waste grouting would be more cost-effective. Table 12 illustrates the estimated amounts of materials needed to produce a cubic meter for the grout formulations studied.

Initial research on grouting of the tank farm vessel process residual heel shows that it is feasible if the heel is diluted to at least $12.5 \%$ of the original concentration. The grouting of full strength wastes was shown to be ineffective. Neutralization by caustics is not recommended due to mixing problems and precipitate formation. Additionally, the use of powdered cements is not recommend due to low strength results. Based on preliminary results, heel displacement by premixed grout recommended. The heel should be diluted with water or aluminum nitrate solutions to double the heel volume and jet off half of the resulting solution. This would be repeated 3 or 4 times to lower to $\mathrm{pH}$ to about 2 . At this point, premixed grout could be added to the heel to raise the level and allow further jetting. A Value Engineering group recommended this method to remove as much heel/waste as possible. During FY-98, the heel grout will undergo thermal cycle and immersion testing. Additionally, the grout formulation used by Savannah River to close their tanks will be evaluated. 
Table 12. Estimated grout formulations to produce a cubic meter of grouted low-activity waste *

\begin{tabular}{|c|c|c|c|c|c|c|c|c|c|c|c|c|c|}
\hline Grout Type & $\begin{array}{l}\text { Liquid } \\
\text { LAW } \\
\left(\mathrm{m}^{3}\right) \\
\end{array}$ & $\begin{array}{c}\text { Treated } \\
\text { Waste } \\
(\mathrm{kg})\end{array}$ & $\begin{array}{c}50 \% \\
\mathrm{NaOH} \\
(\mathrm{kg}) \\
\end{array}$ & $\begin{array}{c}\mathrm{Ca}(\mathrm{OH})_{2} \\
(\mathrm{~kg})\end{array}$ & $\begin{array}{c}\text { Waste } \\
\text { Loading } \\
\text { (wt } \%)\end{array}$ & $\begin{array}{l}\text { Portland } \\
\text { Cement } \\
(\mathrm{kg})\end{array}$ & $\begin{array}{l}\text { Slag } \\
(\mathrm{kg}) \\
\end{array}$ & $\begin{array}{l}\text { Fly } \\
\text { Ash } \\
(\mathrm{kg})\end{array}$ & $\begin{array}{c}\text { Water } \\
(\mathrm{kg})\end{array}$ & $\begin{array}{c}\text { Cured } \\
\text { Density } \\
\left(\mathrm{kg} / \mathrm{m}^{3}\right)\end{array}$ & $\begin{array}{c}28 \text { Day } \\
\text { Strength( } \\
\text { psi) }\end{array}$ & $\begin{array}{c}\text { Grout } \\
\text { Volume } \\
\left(\mathrm{m}^{3}\right)\end{array}$ & $\begin{array}{c}\text { Vol grout } \\
\text { Vol sim. } \\
\text { Ratio } \\
\end{array}$ \\
\hline $\begin{array}{l}\text { Denitrated } \\
\text { LAW grout }\end{array}$ & 4.75 & $\begin{array}{c}\text { Dentr. } \\
548\end{array}$ & $\mathrm{n} / \mathrm{a}$ & $\mathrm{n} / \mathrm{a}$ & $\begin{array}{c}\text { Solids } \\
30.0 \\
\end{array}$ & 253 & 253 & 253 & 519 & 1,826 & 1,600 & 1.0 & 0.21 \\
\hline $\begin{array}{l}\text { Acidic } \\
\text { LAW grout }\end{array}$ & 0.53 & 587 & 29 & $\mathrm{n} / \mathrm{a}$ & $\begin{array}{c}\text { Liquid } \\
30.0\end{array}$ & 269 & 806 & 269 & 0 & 1,960 & 7,200 & 1.0 & 1.87 \\
\hline $\begin{array}{l}\text { Basic LAW } \\
\text { grout }\end{array}$ & 0.63 & 693 & 101 & 117 & $\begin{array}{c}\text { Liquid } \\
42.5\end{array}$ & 72 & 647 & 0 & 0 & 1,630 & 900 & 1.0 & 1.44 \\
\hline
\end{tabular}

* Based on scale-up estimates - not actual results

Table updated 10/22/97 


\section{REFERENCES}

1. Lockheed Martin Idaho Technologies Co., "High-Level Waste Program Plan," INEL-96/122, April 1996.

2. U.S. Nuclear Regulatory Commission Technical Branch of the Low-Level Waste Management and Decommissioning Division, “Technical Position on Waste Form," Revision 1, January, 1991.

3. American Society for Testing and Materials, "Standard Test Method for Compressive Strength of Hydraulic Cement Mortars (Using 2-in. or 50-mm Cube Specimens)," ASTM C109-93, August 15, 1993.

4. U.S. Environmental Protection Agency, "Method 1311, Toxicity Characteristic Leaching Procedure,"Revision 0, July 1992.

5. Code of Federal Regulations 40 CFR 268.48, "Universal Treatment Standards."

6. M. Atkins and F. P Glasser, "Application of Portland Cement-Based Materials to Radioactive Waste Immobilization," Waste Management, Vol. 12, 1992, p. 105-131.

7. Wayne S. Adaska, Stewart W. Tresouthick, and Presbury B. West, Solidification and Stabilization of Wastes Using Portland Cement, Portland Cement Association, Skokie, IL, 1991.

8. C. A. Langton and P. B. Wong, "Properties of Slag Concrete for Low-Level Waste Containment," Ceramic Transactions, Nuclear Waste Management IV, The American Ceramic Society, 1991, p.191-199.

9. R. F. Simmons, H. J. French, M. J. Dalton, and J. R. A. Williams, "Cementation Studies on INEEL Sodium Bearing Waste," AEA Technology Commercial Report AEAT-2178, Issue 1, September 1997. 


\section{M98052563 \\ ||||||||||||||||||||||||||||||||||||||||||||||||||}

Report Number (14) INEKL/EXT- $98-00 / 16$

Publ. Date (11)

Sponsor Code (18)

199802

UC Category (19)

$D O E / E M, X F$
$U C-2000, D O E / E R$

